\title{
Origin of oestrus-associated glycoproteins in bovine oviductal fluid
}

\author{
C. C. Wegner and G. J. Killian* \\ Dairy Breeding Research Center, Department of Dairy and Animal Science, The Pennsylvania State \\ University, University Park, PA 16802, USA
}

\begin{abstract}
Summary. The aim of the present study was to determine whether the synthesis of an oestrus-associated protein found in bovine oviductal fluid varies with oviductal region, stage of cycle or day of pregnancy. Explant culture was performed using oviducts recovered from naturally cycling animals either at oestrus or 12-14 days after oestrus. Three oviductal regions, the preampulla, ampulla and isthmus, were cultured individually in the presence of $20 \mu \mathrm{Ci}\left[{ }^{35}\right.$ S]methionine in serum-free medium for $6 \mathrm{~h}$ at $37^{\circ} \mathrm{C}$. Synthesis of oestrus-associated protein was assessed by one-dimensional SDS-PAGE, fluorography and densitometry of radiolabelled bands. Significantly more oestrus-associated protein was synthesized by the ampullar region of the oviduct, although it was detected in explant culture media from both the isthmic and preampullar regions. A polyclonal antibody produced against oestrus-associated protein was used to localize the protein in paraffin-embedded sections of oviductal explant cultures and other bovine tissues. Localization of the protein in oviductal tissue sections varied with stage of cycle (oestrus $>$ luteal $>$ pregnant) and region of oviduct (ampulla $>$ preampulla/isthmus). These findings indicate an effect of oviductal region and hormonal state (cycling versus pregnant) on the synthesis and secretion of the oestrus-associated protein. Lectin affinity studies indicated that galactosyl $(\beta 1,3) \mathrm{N}$ acetylgalactosamine and $\mathrm{N}$-acetylglucosamine residues are associated with the oestrusassociated protein.
\end{abstract}

Keywords: oviductal fluid; protein synthesis; oestrous cycle; glycoprotein; cow

\section{Introduction}

The oviduct provides the microenvironment where fertilization and early embryo development occur. Although little is known of the specific function of components in oviductal fluid, coculture of embryos with oviductal cells (Gandolfi \& Moor, 1987) or addition of oviductal fluid facilitates embryo development (Kille \& Hamner, 1973). The observation that some oviductal proteins associate with either eggs (Shapiro et al., 1974; Fox \& Shivers, 1975; Leveille et al., 1987; Wegner \& Killian, 1991) or spermatozoa (Sutton et al., 1984a; Lippes \& Wagh, 1989; McNutt et al., 1991) supports the idea that some of these proteins have a role in fertilization.

Evidence has accumulated for the synthesis and secretion of oviduct-specific proteins coincident with ovulation, fertilization and early embryo development. Oviduct-specific proteins are synthesized by oviductal explants obtained from cows in oestrus (Geisert et al., 1987; Malayer et al., 1988; Boice et al., 1990). Selective synthesis of oviductal proteins during gamete transport and early embryo development in numerous species suggests a related function in these events, particularly in the light of the observation that some oviductal fluid proteins associate with gametes and early embryos. One-dimensional SDS-PAGE of oviductal fluid collected daily from indwelling oviductal

\footnotetext{
*Corresponding author.
} 
cannulae in cows demonstrated that an oestrus-associated glycoprotein is produced in vivo (Gerena \& Killian, 1990). The molecular weight of this glycoprotein identified from cannulaederived oviductal fluid (this laboratory) and oviductal flushings (Boice et al., 1990) was approximately $85-95 \mathrm{kDa}$. The object of the present study was to localize this oestrus-associated glycoprotein in different regions of the oviduct and to determine its production under the hormonal conditions associated with follicular and luteal stages of the oestrous cycle and gestation.

\section{Materials and Methods}

\section{Preparation of antiserum to oestrus-associated protein}

Samples of oviductal fluid were collected daily from the oviduct through indwelling cannulae as previously described by Kavanaugh \& Killian (1988). Because it was not possible to observe cows for standing oestrus without putting the catheters at risk of evulsion, the stage of the oestrous cycle was determined by radioimmunoassay of progesterone concentration in serum (Killian et al., 1989). Samples of oviductal fluid collected on days when the progesterone concentration was $\geqslant 1.5 \mathrm{ng} \mathrm{ml}$ ' were considered luteal-stage samples, whereas those recovered on days when the progesterone concentration was $<1.5 \mathrm{ng} \mathrm{ml}$ ' were considered non-luteal samples. Non-luteal samples were further divided into non-luteal 1 (NL1) and non-luteal 2 (NL2). Samples pooled for NL2 included oviductal fluid from days when the progesterone concentration in serum was $<1.5 \mathrm{ng} \mathrm{m}^{-1}$, starting with the day of oestrus and ending on the day before the rise in progesterone concentration to $\geqslant 1.5 \mathrm{ng} \mathrm{ml}$ '. Days of oestrus and ovulation were estimated to occur at 4 and 3 days before the first rise in serum progesterone to $\geqslant 1.5 \mathrm{ng} \mathrm{ml}^{-1}$, respectively. Samples of oviductal fluid collected when the progesterone concentration was $<1.5 \mathrm{ng} \mathrm{ml}$ ' but before oestrus, were defined as NLI.

Samples of oviductal fluid pooled for NL2 ( $1.9 \mathrm{mg}$ protein) were resolved on a one-dimensional $5-12.5 \%$ lineargradient, preparative curtain SDS-PAGE gel with 4\% stacking gel (Laemmli, 1970). Coomassie-stained bands corresponding to oestrus-associated protein were cut from this gel, frozen in liquid nitrogen and pulverized. Phosphate-buffered saline was used to resuspend $400 \mu \mathrm{l}$ of pulverized material ( $25 \mu \mathrm{g}$ protein) before homogenizing with an equal volume of either Freund's complete or incomplete adjuvant. The protein concentration was estimated by densitometric analysis of the Coomassie-stained gels to determine the percentage of oestrus-associated protein present in the total-protein lane. Subcutaneous injections of $25 \mu \mathrm{g}$ of oestrus-associated protein were made between the shoulders of a male New Zealand white rabbit at two week intervals for six weeks. Blood was then collected from the marginal ear vein and serum was stored in $1 \mathrm{ml}$ aliquots at $-20^{\circ} \mathrm{C}$ until used.

\section{Specificity of polyclonal antiserum}

Specificity was determined by western blotting. One-dimensional electrophoresis of blood serum, follicular fluid and oviductal fluid was performed as previously described (Gerena \& Killian, 1990). Two-dimensional electrophoresis followed the method of O'Farrell (1975). After electrophoresis, gels were equilibrated for $30 \mathrm{~min}$ in blotting buffer (25 mmol Tris 1 ', $192 \mathrm{mmol}$ glycine 1 ', $0.1 \% \mathrm{SDS}, 20 \% \mathrm{MeOH}, \mathrm{pH} 8.3$ ) and then run at 100 volts per gel for $2 \mathrm{~h}$ to transfer the proteins to nitrocellulose paper. Blots were incubated in $3 \%$ hydrogen peroxide to inactivate endogenous peroxidases. Blots were blocked in 5\% normal goat serum (NGS: Pel Freeze Biologicals, Rogers, KS) in $20 \mathrm{mmol}$ Tris-buffered saline (TBS) 1 ' with $0.05 \%$ Tween $20, \mathrm{pH} 7.6$ before probing with antiserum to oestrus-associated protein diluted 1:1000 with 1\% NGS in TBS-Tween buffer $\left(1 \mathrm{~h}, 37^{\circ} \mathrm{C}\right)$. All subsequent washes contained $1 \%$ NGS. Antigen antibody complexes were visualized using a second antibody (anti-rabbit IgG-peroxidase conjugate, 1:2000; Sigma Chemical Co., St Louis, MO) and 3-chloro-1-napthol substrate (Sigma).

\section{Culture of oviductal explants}

Oviducts were recovered from cows with normal oestrous cycles that were killed either at behavioural oestrus $(n=3)$ or 12 14 days later $(n=3)$. On the day of death, blood samples were taken and later assayed for serum progesterone by radioimmunoassay to confirm the hormonal status of each cow. Each oviduct was trimmed of surrounding tissue and divided into preampulla, ampulla and isthmus. Each region was cut open longitudinally and dissected into $3-4 \mathrm{~mm}$ pieces of tissue containing epithelium, stroma and muscle layers. Tissue (1 g wet weight) was cultured in RPMI 1640 (Sigma)/Dulbecco Minimum Essential Medium (Gibco, Grand Island, NY) serum-free culture medium supplemented with glucose $\left(17 \mathrm{mmol}^{\prime}\right)$, glutamine $(2 \mathrm{mmoll})$, epidermal growth factor $\left(25 \mathrm{ng} \mathrm{ml}^{1}\right)$, insulin-transferrin-sodium selenite $\left(5 \mu \mathrm{g} \mathrm{ml}\right.$ ', $5 \mu \mathrm{g} \mathrm{ml}^{-1}, 5 \mathrm{ng} \mathrm{ml}$ ', respectively; Sigma) and $20 \mu \mathrm{Ci}$ [ ${ }^{35}$ S]methionine, (Dupont/New England Nuclear, Boston, MA) for $6 \mathrm{~h}$ at $37^{\circ} \mathrm{C}$ in humidified $5 \% \mathrm{CO}_{2}$-air. After $6 \mathrm{~h}$, radioactive conditioned medium was recovered and explants were rinsed with fresh unlabelled medium and cultured for an additional $14 \mathrm{~h}$ in unlabelled medium. Conditioned culture medium was centrifuged ( $1000 \mathrm{~g}$ for $10 \mathrm{~min})$ to pellet cells and the nitrogen-gassed supernatant was frozen at $-20^{\circ} \mathrm{C}$. Aliquots were removed for protein assay 
(Lowry et al., 1951) and liquid scintillation counting. At $6 \mathrm{~h}$ and $20 \mathrm{~h}$, explant samples were removed and fixed in picric acid-formalin for histology.

\section{Histology}

Fixed explant sections were embedded in paraffin and sectioned at $8 \mu \mathrm{m}$. Uptake of ${ }^{35}$ S $]$ methionine was determined by treatment of oviduct sections with Ilford KD-50 nuclear research emulsion (Polysciences, Warrington, PA: 14 days in dark, $\left.5^{\circ} \mathrm{C}\right)$ before development with Dektol $\left(1: 1\right.$ with distilled $\left.\mathrm{H}_{2} \mathrm{O}\right)$ for 2 min and counterstaining with Gill's haematoxylin-eosin for $2 \mathrm{~min}$.

Oestrus-associated protein was localized in oviductal explant tissue sections with the antiserum and antigenantibody complexes were visualized using goat anti-rabbit IgG-peroxidase conjugate and diaminobenzidine (DAB) substrate (Sigma). Tissues tested included cervix, uterus, ovary and oviduct from cows killed during behavioural oestrus, mid-luteal stage or pregnancy (32-270 days). Oviducts from ten pregnant cows were recovered at death and the approximate day of pregnancy (32-270) was determined by the length from fetal crown to rump (Tanabe, 1970). Non-reproductive tissues examined included salivary gland, bladder, mammary gland, spleen, heart, lung, muscle, small intestine, ureter and kidney. Sections were incubated in $1 \% \mathrm{H}_{2} \mathrm{O}_{2}$ solution in TBS containing $0 \cdot 1 \% \mathrm{BSA}, 0 \cdot 1 \%$ Triton X-100 ( $\mathrm{pH} 7.6)$ for $2 \mathrm{~h}$ at room temperature. Sections were washed in TBS for $15 \mathrm{~min}$, before incubation overnight at $4^{\circ} \mathrm{C}$ with either preimmune rabbit serum (1:500) or antiserum to oestrus-associated protein (1:1000). Washed sections were incubated in 1\% goat serum in TBS for $30 \mathrm{~min}$ before incubation with second antibody (goat anti-rabbit IgG peroxidase conjugate) for $60 \mathrm{~min}$ at room temperature. After rinsing in TBS, sections were reacted in DAB solution (10 mg DAB in $80 \mathrm{ml} 0.05 \mathrm{~mol}$ Tris $\left.1{ }^{\prime}, 0.03 \% \mathrm{H}_{2} \mathrm{O}_{2}, \mathrm{pH} 7.6\right)$. The reaction was stopped by $1 \mathrm{~min}$ immersion in $0.025 \mathrm{~mol}$ Tris $1^{-1}$ before dehydration and mounting with Permount (Fisher Scientific; Pittsburgh, PA).

\section{Autoradiography}

Conditioned culture medium was filtered by centrifugation through $10000 \mathrm{M}$. Centricell concentrators (Polysciences, Warrington, PA) to remove free $\left[{ }^{35} \mathrm{~S}\right]$ methionine and other amino acids prior to lyophilization. Conditioned medium proteins $(100 \mu \mathrm{g}$ protein per lane or $150000 \mathrm{~d}$.p.m. per lane) were resolved on one-dimensional $5-12.5 \%$ gradient gel as described previously. Two-dimensional electrophoresis gels $(150 \mu \mathrm{g}$ protein per gel) were prepared by the method of O'Farrell (1975). Gels were incubated with ENTENSIFY universal autoradiography solution (Dupont/New England Nuclear, Boston, MA) prior to drying at $80^{\circ} \mathrm{C}$ in a slab gel dryer (Bio-Rad, Melville, NY) and exposed to X-Omat XAR-2 X-ray film (Kodak Co., Rochester, NY) for 14 days at $-70 \mathrm{C}^{\circ}$. Film was developed in Kodak GBX developer $\left(5 \mathrm{~min}, 20^{\circ} \mathrm{C}\right)$. Quantitative analysis of X-ray film was performed by video densitometer scanning using Model 620 video densitometer (Bio-Rad) interfaced with an Epson Equity I computer (Seiko Epson Corporation, Nagano, Japan).

\section{Detection of lectin-reactive sites on western blots of oviductal fluid}

Proteins from non-luteal oviductal fluid were separated on one-dimensional SDS-PAGE gels and transferred to nitrocellulose paper (Towbin et al., 1979) before probing with various lectins. Blots were probed with lectins using the Vectastain biotinylated lectins kit, Vectastain $\mathrm{ABC}$ reagent (Vector Laboratories, Burlingame, $\mathrm{CA}$ ) and DAB substrate. The type and carbohydrate specificity of lectins used were Ulex europeaeus agglutinin I (UEA; $\alpha$-linked fucose residues), soybean agglutinin (SBA; terminal $\alpha$ - or $\beta$-linked $N$-acetylgalactosamine), Dolchos biflorus agglutinin (DBA; $\alpha$-linked $N$-acetylgalactosamine), peanut agglutinin (PNA; galactosyl $(\beta$-1,3) $N$-acetylgalactosamine), wheat germ agglutinin (WGA; $N$-acetylglucosamine), concanavalin A (ConA; $\alpha$-linked mannose) and Ricinus communis agglutinin I (RCA; galactose or $\mathrm{N}$-acetylgalactosamine).

Blot strips were incubated in $3 \% \mathrm{H}_{2} \mathrm{O}_{2}$ in Tris-buffered saline with Tween 20 (TTBS; $0.1 \%$ Tween 20 in $0.1 \mathrm{~mol}$ Tris 1 ' $, 0.9 \% \mathrm{NaCl}, \mathrm{pH} 7.5$ ) for $5 \mathrm{~min}$ to inactivate any endogenous peroxidases. Nonspecific binding sites were blocked using TTBS for $30 \mathrm{~min}$ before incubating the blot with biotinylated lectins. The concentrations used for each lectin were: PNA and WGA ( $\left.8 \mu \mathrm{g} \mathrm{ml}{ }^{~}{ }^{\prime}\right)$, ConA and RCA (0.8 $\mu \mathrm{g} \mathrm{ml} \mathrm{'),} \mathrm{DBA,} \mathrm{UEA} \mathrm{and} \mathrm{SBA}\left(16 \mu \mathrm{g} \mathrm{ml}^{-1}\right)$. Individual blot strips were incubated with lectins for $60 \mathrm{~min}$, washed three times in TTBS for $5 \mathrm{~min}$ each and then incubated with avidin-biotin peroxidase conjugate ( $\mathrm{ABC}$ reagent, Vector Laboratories) for $45 \mathrm{~min}$. The $\mathrm{ABC}$ reagent was made as recommended by Vector, then diluted 1:5 to reduce background. Blots were washed in TTBS as before and then developed with DAB substrate. Specificity of lectin reaction was determined by incubation of control strips with lectin plus specific sugar: SBA and DBA (200 mmol $N$-acetyl galactosamine ! 1 ), UEA ( $50 \mathrm{mmol}$ fucose $\left.1^{-1}\right)$, WGA (500 mmol $N$-acetyl glucosamine $\left.\mathrm{l}^{-1}\right)$ and PNA (200 mmol lactose $\left.\mathrm{l}^{-1}\right)$. Bands corresponding to oestrus-associated protein were identified in a separate blot strip by incubation with antiserum to oestrus-associated protein, goat anti-rabbit IgG-peroxidase conjugate and DAB substrate.

\section{Detection of glycosylated proteins on one-dimensional SDS-PAGE gels}

Schiff's reagent (Glossman \& Neville, 1971) was used to detect glycosylated proteins in one-dimensional SDSPAGE gels of oviductal fluid collected through indwelling cannulae in the ampulla and isthmus, pooled into NL1, NL2 and L fractions. 


\section{Statistical analysis}

Statistical analysis of densitometry scans was performed by analysis of variance and Tukey Studentized Range (HSD) test (SAS, 1985), to detect effects of stage of cycle (mid-luteal or oestrus) and oviductal region (preampulla, ampulla or isthmus).

\section{Results}

The concentration of progesterone in serum was $\leqslant 0.1 \mathrm{ng} \mathrm{ml}^{-1}$ in cows killed within $24 \mathrm{~h}$ of standing heat and $>1.5 \mathrm{ng} \mathrm{ml}^{-1}$ in animals killed $13-14$ days after observation of standing heat.

\section{Specificity of antiserum to oestrus-associated protein and its characterization in oviductal fluid}

When western blots of one-dimensional gels of bovine serum, follicular fluid and oviductal fluid were probed with antiserum to oestrus-associated protein, the antiserum reacted only in lanes containing oviductal fluid. Antiserum to oestrus-associated protein recognized two bands at $97 \mathrm{kDa}$ in oviductal fluid, as well as a higher molecular weight species of approximately $200 \mathrm{kDa}$ (Fig. la, b). Reactivity also persisted at approximately $66 \mathrm{kDa}$ even in the presence of $1 \% \mathrm{BSA}$ in the antibody dilution buffer, suggesting that these antigens, although comigrating with BSA, were not specific for BSA. The strongest antiserum reaction was observed in the lane corresponding to non-luteal oviductal fluid.

Similarly, when ampullar or isthmic oviductal fluid collected by cannula was reacted with antiserum to oestrus-associated protein, non-luteal oviductal fluid reacted more strongly than luteal oviductal fluid (data not shown). Schiff's staining of regional oviductal fluid proteins separated by one-dimensional SDS-PAGE showed staining at approximately $97 \mathrm{kDa}$ in lanes containing ampullar oviductal fluid pooled for the non-luteal phase of the oestrous cycle. Isthmic fluid showed no reaction at $97 \mathrm{kDa}$, although all lanes contained some Schiff reactive material below BSA ( $<66 \mathrm{kDa}$ ). Pore-limited material at the stacking-resolving gel interface reacted strongly with Schiff's reagent, especially in lanes containing oviductal fluid from NL2.

Two-dimensional blots of non-luteal oviductal fluid from ampulla reacted with antiserum to oestrus-associated protein and revealed a prominant area of reaction at pI $5 \cdot 2$ and $97 \mathrm{kDa}$ (Fig. Ic). Extending in both directions from this $97 \mathrm{kDa}$ spot were reactive areas similar to those observed in autoradiograms of the radiolabelled proteins present in conditioned culture medium of ampulla explant cultures (Fig. 2).

Oviductal fluid recovered from an indwelling cannula of a cow on days $60,90,119,149,180$ and 200 of gestation exhibited a positive reaction with antiserum to oestrus-associated protein on all days of pregnancy examined (Fig. 3). Proteins in oviductal fluid from pregnant cows also reacted with Schiff's reagent on one-dimensional SDS-PAGE gels on all days of pregnancy examined, but the reaction was weaker than that observed in oviductal fluid from cows in oestrus (data not shown).

\section{Characterization of secretions from oviductal explant culture}

Tissue sections of oviductal explants treated with radiosensitive emulsion showed $\left[{ }^{35} \mathrm{~S}\right] \mathrm{methionine}$ uptake localized exclusively in epithelium cells, predominantly along the luminal edge (data not shown). Stromal tissue was devoid of granules or contained few granules, comparable to tissue-free areas of the slide.

Incorporation of $\left[{ }^{35} \mathrm{~S}\right]$ methionine into luteal- and oestrous-explant tissue ranged from 1.482 to $6.693 \mu \mathrm{Ci} \mathrm{g} \mathrm{g}^{-1}$ wet weight explant. The percentage incorporation of available $\left[{ }^{35}\right.$ S]methionine ranged from $8 \cdot 0 \%$ to $35 \cdot 8 \%$. Explants recovered at oestrus incorporated significantly $(P<0.05)$ more $\left[{ }^{35}\right.$ S]methionine than luteal stage explants (Fig. 4). Region of oviduct 

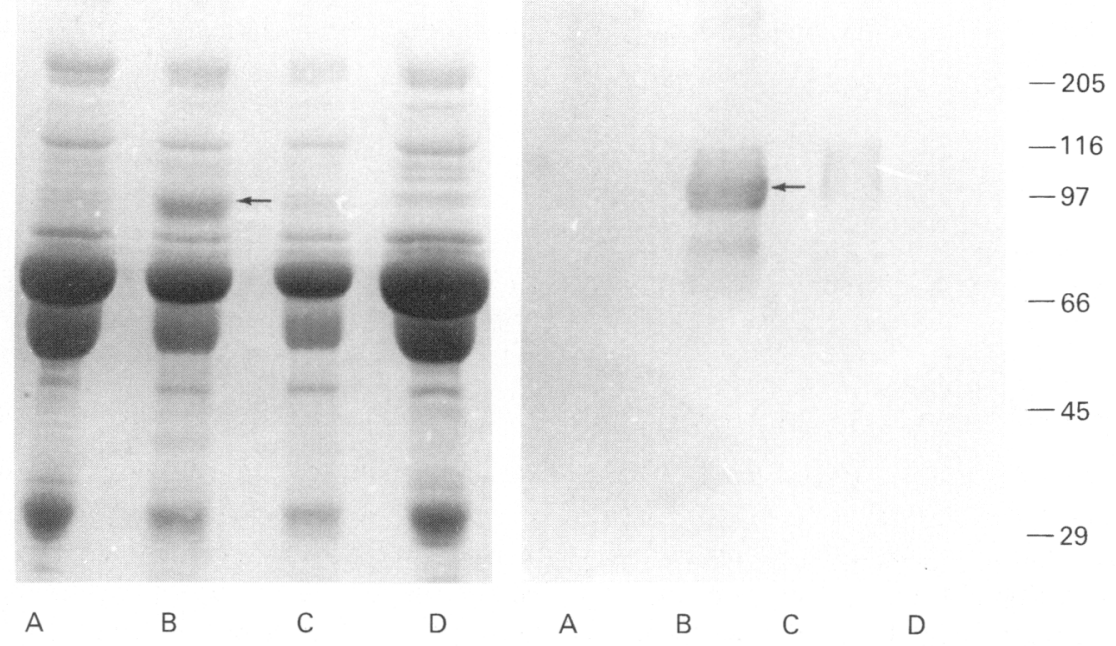

(c)

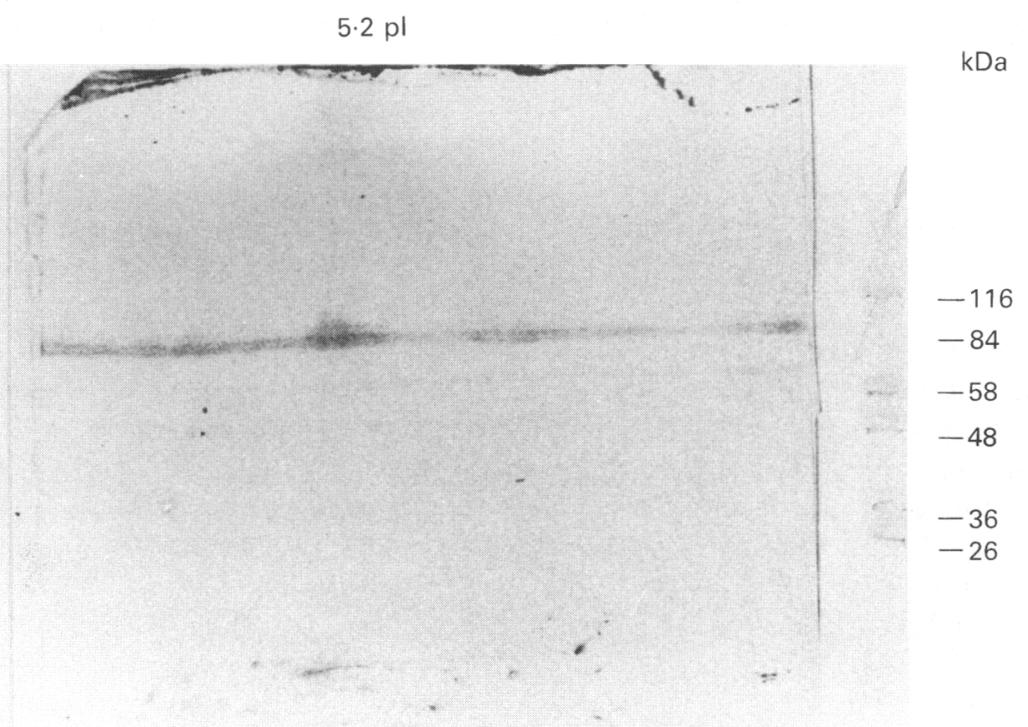

Fig. 1. Western blots of samples of $100 \mu \mathrm{g}$ protein from blood serum (lane A), pooled nonluteal (lane B) and luteal oviductal fluid (lane C) or follicular fluid (lane D) separated on a one-dimensional SDS-PAGE gel and (a) stained with Coomassie or (b) transferred to nitrocellulose. The western blot was then reacted with antiserum to oestrus-associated protein. Arrow indicates the $97 \mathrm{kDa}$ protein in non-luteal and luteal oviductal fluid. (c) A western blot of a two-dimensional SDS-PAGE gel of oviductal fluid from the ampulla collected from an indwelling cannula during the non-luteal phase of the oestrous cycle showing the reaction of antiserum to oestrus-associated protein with a $97 \mathrm{kDa}$ protein at multiple isoelectric points.

had no effect $(P=0 \cdot 1)$ on $\left[{ }^{35}\right.$ S $]$ methionine incorporation and region by stage interaction was not significant $(P=0 \cdot 89)$.

The relative amount of oestrus-associated protein synthesized per region in each cycle stage was determined by the Bio-Rad one-dimensional-analyst program from the area $\left(\mathrm{mm}^{2}\right)$ under the 


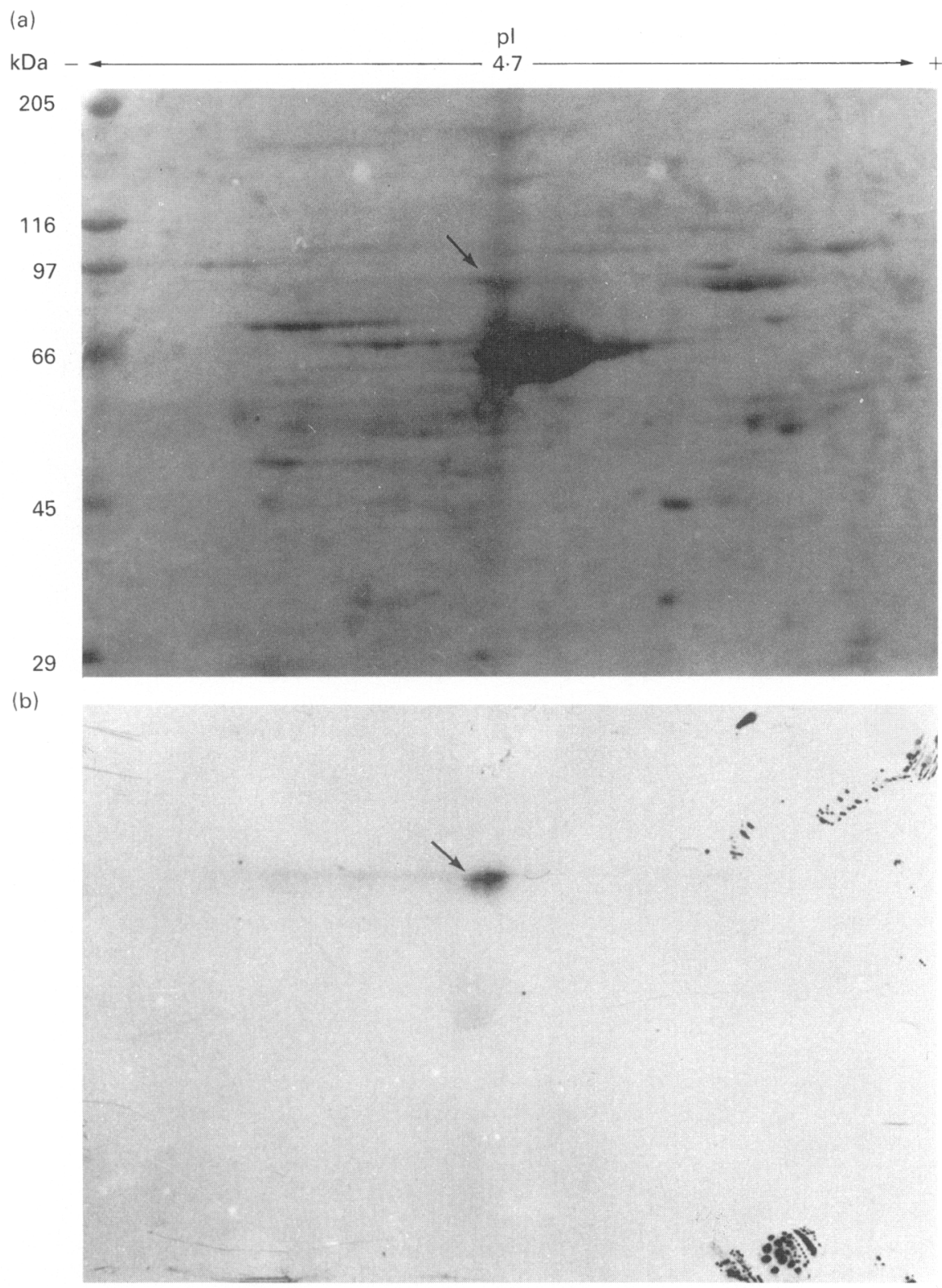

Fig. 2. Two-dimensional SDS-PAGE gel stained with Coomassie of (a) supernatant proteins produced by ampullar explants taken at oestrus after $6 \mathrm{~h}$ incubation in $20 \mu \mathrm{Ci}\left[{ }^{35} \mathrm{~S}\right]$ methionine. Approximately $120 \mu \mathrm{g}$ of protein (100000 c.p.m.) was separated by two-dimensional electrophoresis and exposed to Kodak X-Omat film for 8 weeks at $-70^{\circ} \mathrm{C}$. Arrows indicate location of $97 \mathrm{kDa}$ protein in (a) the gel and (b) the corresponding autoradiograph.

peak of a graph of optical density versus relative mobility of oestrus-associated protein on onedimensional SDS-PAGE autoradiograms (Fig. 5). At $6 \mathrm{~h}$ and $20 \mathrm{~h}$ of culture, oestrus-stage explants synthesized more oestrus-associated protein $(P<0.05$ at $6 \mathrm{~h}, P<0.01$ at $20 \mathrm{~h})$ than luteal-stage explants (Fig. 6). Oestrus explants analysed at $6 \mathrm{~h}$ also showed a region effect with ampullar 
(a)

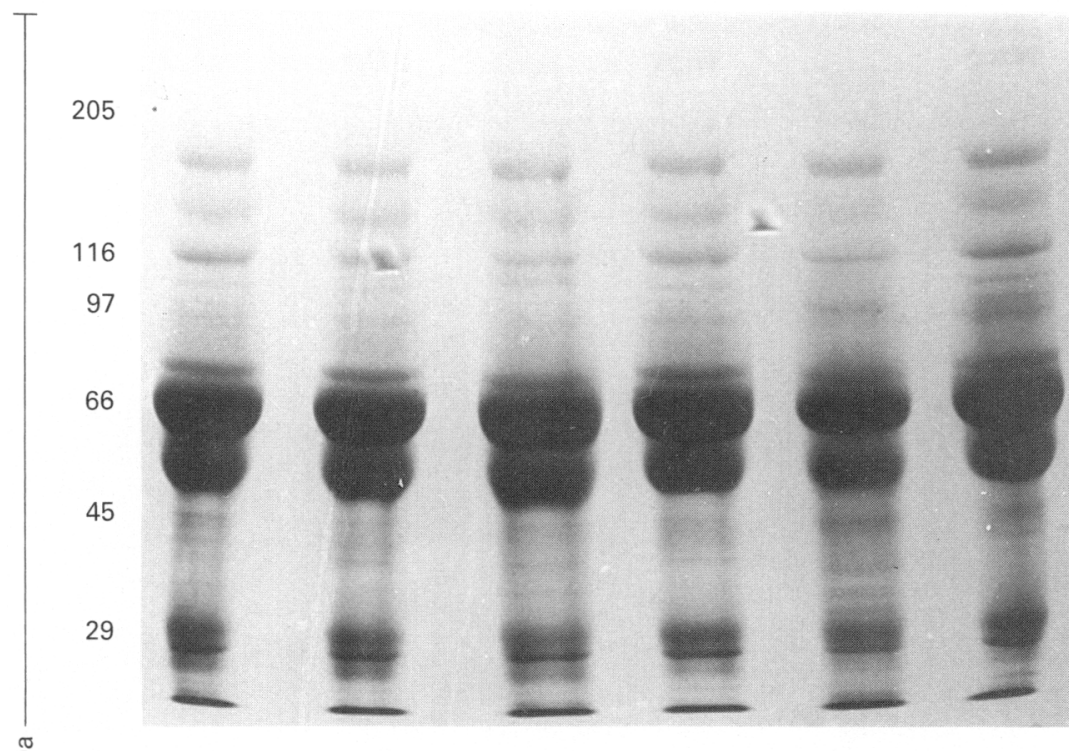

(b)

Fig. 3. One-dimensional SDS-PAGE gel or proteins stained with Coomassie ( $100 \mu \mathrm{g}$ per lane) in oviductal fluid obtained from an indwelling oviductal cannula during (a) gestation and (b) the corresponding western blot probed with antiserum to oestrus-associated protein. Lanes A-F correspond to days $60,90,119,149,180$ and 200 , respectively, of pregnancy in one cow sampled throughout gestation.

explants synthesizing significantly more oestrus-associated protein than either the preampulla or isthmus regions $(P<0 \cdot 01)$. At oestrus, preampulla and isthmus regions did not synthesize significantly $(P>0.3)$ different amounts. At $20 \mathrm{~h}$ of culture, no regional effect on oestrus-associated protein synthesis was observed. 


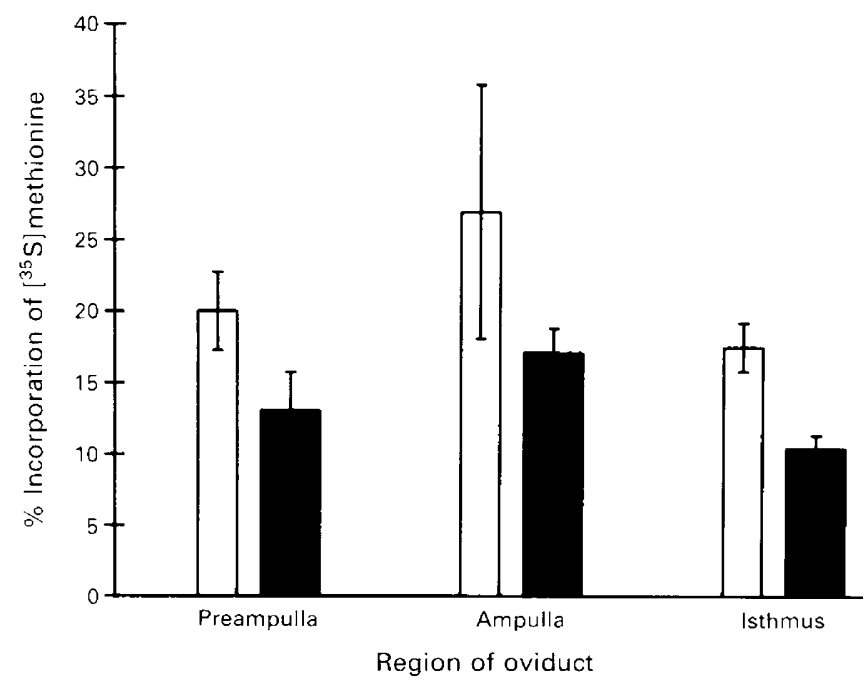

Fig. 4. Oviductal explants from preampulla, ampulla and isthmus obtained at either oestrus (open bars) or mid-luteal phase (solid bars) of the cycle and cultured with $20 \mu \mathrm{Ci}\left[{ }^{35} \mathrm{~S}\right]$ methionine for $6 \mathrm{~h}$ at $37^{\circ} \mathrm{C}$. Data are expressed as the percentage of available $\left[{ }^{35} \mathrm{~S}\right] \mathrm{methionine}$ incorporated by each explant $(8 \cdot 0-35 \cdot 8 \%)$ for three cows per stage. Incorporation of $\left[{ }^{35} \mathrm{~S}\right]$ methionine was significantly greater $(P \leqslant 0 \cdot 05)$ in explants prepared for culture at oestrus. (Bars indicate mean \pm SEM.)

Analysis of variance indicated a significant effect of region on the percentage of oestrusassociated protein synthesized at oestrus for three cows at $6 \mathrm{~h}(P<0.005)$ and at $20 \mathrm{~h}(P<0 \cdot 05)$. The percentage of oestrus-associated protein synthesized was significantly greater for ampulla regions ( $P<0.01$ at 6 and $20 \mathrm{~h}$, respectively), than for isthmus or preampulla regions.

\section{Immunocytochemical localization of oestrus-associated protein}

The reaction of antiserum to oestrus-associated protein with oviductal tissue was observed only in non-ciliated epithelial cells, never in muscle or stroma. However, cilia were frequently stained, especially if adjacent non-ciliated cells were stained. Although some staining was observed in all oviduct regions, the percentage of cells reacting varied with stage of the oestrous cycle. More than $50 \%$ of the cells showed some reaction in oestrus-stage explants. In luteal tissue, the frequency of staining decreased to $0-40 \%$ typically, and only rarely was a staining frequency of $50 \%$ or greater observed. Within the same stage of the cycle, the number of cells that reacted with the antiserum differed with oviduct region. More reactive cells were observed in the preampulla and ampulla than in the isthmus. In addition, although staining in the isthmus was generally restricted to discrete structures, staining in the preampulla and ampulla was often found throughout the cell cytoplasm.

Histological sections from various non-oviductal tissues that were probed with the antiserum or preimmune serum did not react with any tissue except spleen. Subsequent use of second antibody alone showed that this treatment was responsible for the spleen reaction. No other tissue tested reacted with the second antibody alone, and antiserum to oestrus-associated protein reacted only with oviductal tissue.

Oviductal tissue recovered from pregnant cows killed on days $32,65,75,85,90,125,150,175$, 200 and 270 of pregnancy and reacted with antiserum to oestrus-associated protein generally had staining comparable to that of luteal oviductal tissue (i.e. $0-50 \%$ ). Only at 150 days of pregnancy did cell staining frequency exceed $50 \%$ in any region. Negligible staining $(<10 \%)$ was observed on days $65,75,85$ and 90 in all regions except the ampulla $(50 \%)$ on day 65 . 
(a)

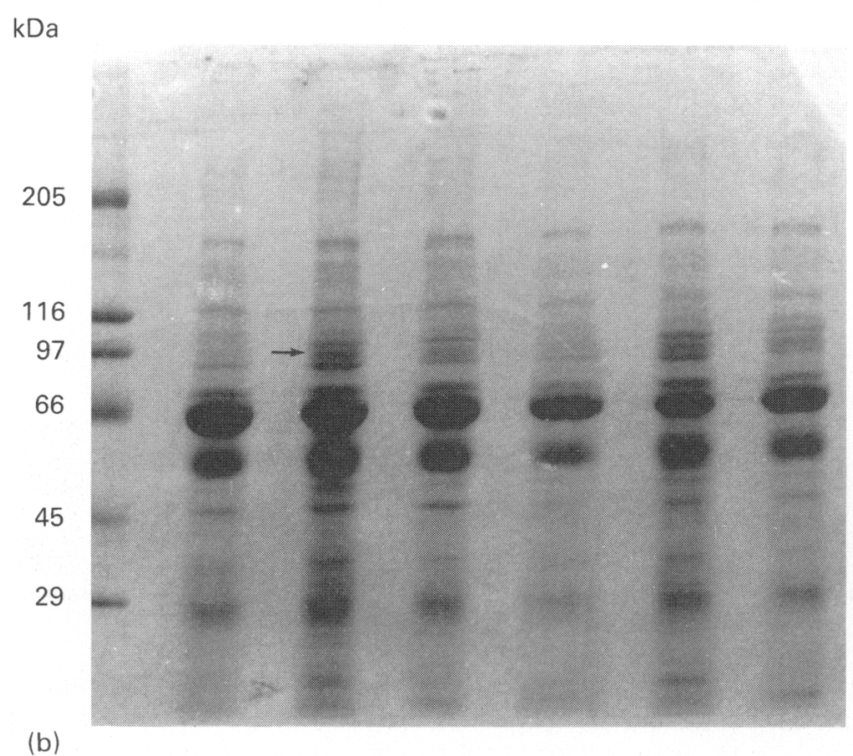

97
A
B
C
E
$\mathrm{F}$

Fig. 5. (a) Representative one-dimensional SDS-PAGE gel stained with Coomassie and (b) corresponding autoradiograph of $\left[{ }^{35} \mathrm{~S}\right]$ methionine-labelled proteins secreted from three regions of the oviduct at oestrus after 6 or $20 \mathrm{~h}$ of explant culture. Radiolabelled proteins were separated on a 5-12\% gradient gel (100 $\mu$ g per lane): lane A, preampulla; lane B, ampulla; lane C, isthmus after $6 \mathrm{~h}$ culture. Lanes D, E, and F are conditioned medium from the same regions, respectively, after $20 \mathrm{~h}$ culture. Arrow indicates the location of oestrus-associated protein at $97 \mathrm{kDa}$. Note the enhanced radiolabel in proteins from the ampulla region at oestrus.

\section{Lectin binding}

Lectin reactivity of non-luteal oviductal fluid was present at $97 \mathrm{kDa}$ with SBA, DBA, WGA and PNA. ConA and RCA did not react with non-luteal oviduct fluid at $97 \mathrm{kDa}$. However, at the concentration of competitive sugars used, only WGA and PNA binding could be displaced (Fig. 7). 
(a)

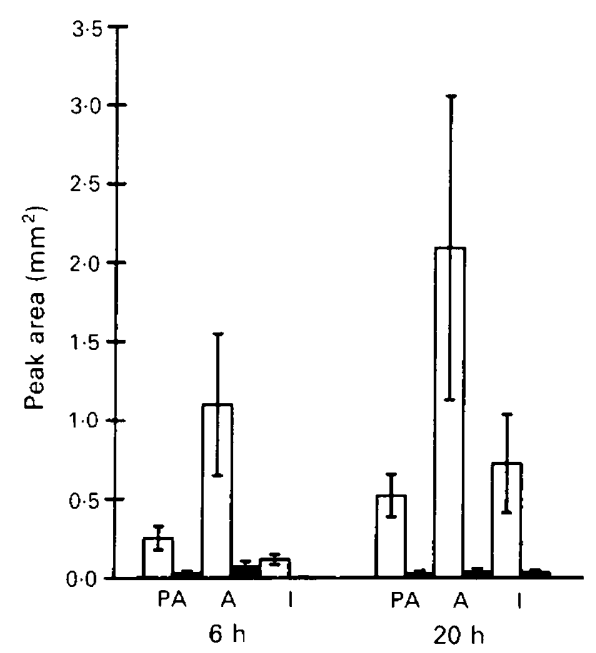

(b)

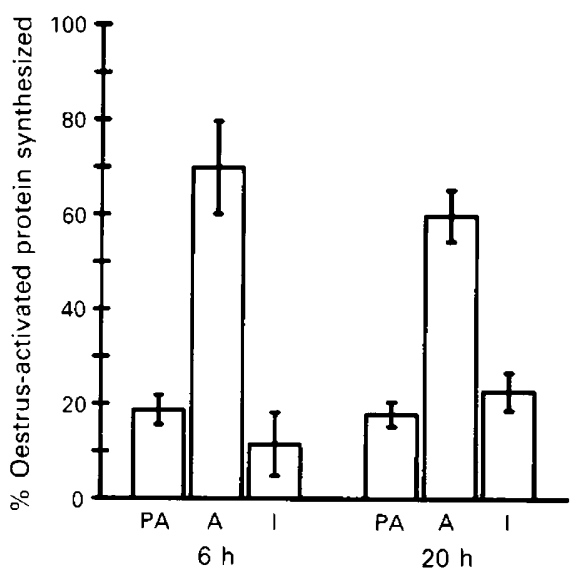

Fig. 6. (a) Relative secretion of oestrus-associated protein by cultured explants recovered from three oviductal regions at two different stages of the oestrous cycle ( $\square$ at oestrus, $\square$ luteal stage). Peak area $\left(\mathrm{mm}^{2}\right)$ under the curve of optical density versus relative mobility was generated by densitometry of autoradiographs of $\left[{ }^{35}\right.$ S]methionine-labelled proteins secreted by oviductal explants incubated for either 6 or $20 \mathrm{~h}$. (b) The percentage secretion of oestrus-associated protein contributed by each oviductal region at oestrus after incubation for 6 or $20 \mathrm{~h}$. PA: preampulla; A: ampulla; I: isthmus.

\section{Discussion}

We observed that several oviductal proteins were synthesized in vitro by bovine oviductal explants. The primary protein synthesized $\left(M_{\mathrm{r}}=97 \mathrm{kDa}, \mathrm{pI}=4.7\right)$ was predominant at oestrus. These findings agree with those of Malayer et al. (1988) and Boice et al. (1990) who identified a $97 \mathrm{kDa}$ protein secreted by oviductal explants, which was greatly amplified in tissues taken at oestrus. A similar oestrus-associated protein $\left(M_{\mathrm{r}}=80-90 \mathrm{kDa}, \mathrm{pl}=4.7\right)$ has been identified previously in sheep (Sutton et al., 1984b, 1985).

Using conditioned medium from ampullar and isthmic explants and oviductal flushings obtained from cows killed at oestrus and other days of the cycle, Boice et al. (1990) identified a prominent $97 \mathrm{kDa}$ protein at oestrus on fluorographs of one- and two-dimensional electrophoresis gels. This protein was not detected in conditioned medium from explants of ovarian tissue, endometrium, liver, lung, kidney and mammary gland, suggesting it was oviduct specific. The data presented in the present study confirm and extend the observations of Boice et al. (1990). The present study also indicates that the $97 \mathrm{kDa}$ protein is oviduct specific as determined from western blots of oviductal fluid, follicular fluid and blood serum and immunocytochemistry of various nonoviductal tissues. Furthermore, detection of oestrus-associated protein in oviductal fluid collected via cannulae (the present study) and oviductal flushings (Boice et al., 1990) suggests that collection of oviductal fluid by these methods provides an alternative source to conditioned medium for the recovery of physiologically relevant oviductal fluid. Analysis in the current study of cannuladerived, non-luteal oviductal fluid by western blotting demonstrates that either more oestrusassociated protein or a more antigenic form of the protein was secreted in vivo at about the time of oestrus.

The present study extends the regional observations of Boice et al. (1990) using explant culture with an examination of the preampulla region of the oviduct. Unlike Boice et al. (1990), we report 
(a)

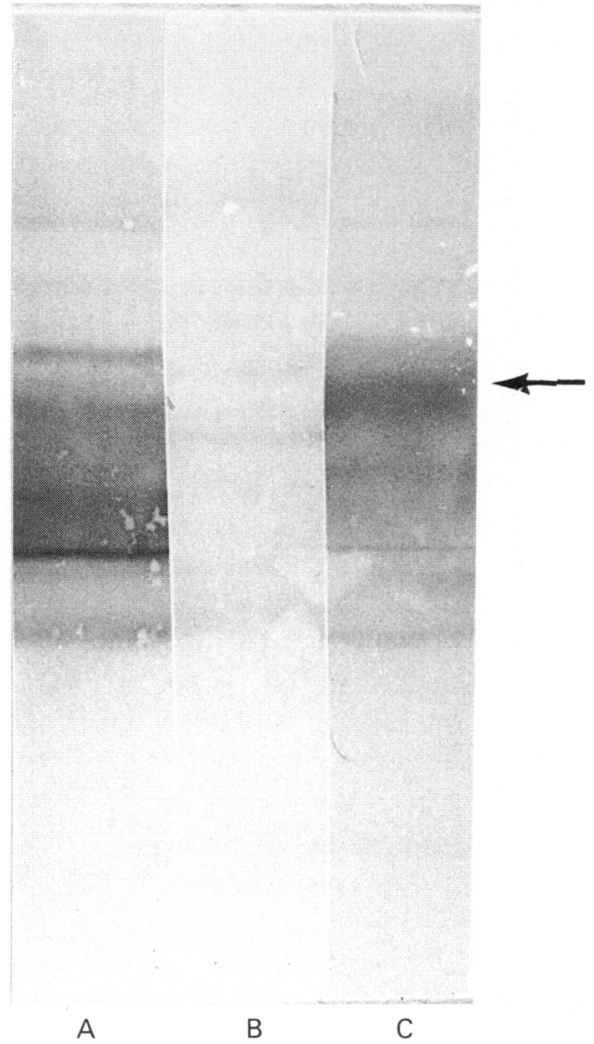

(b)

WGA

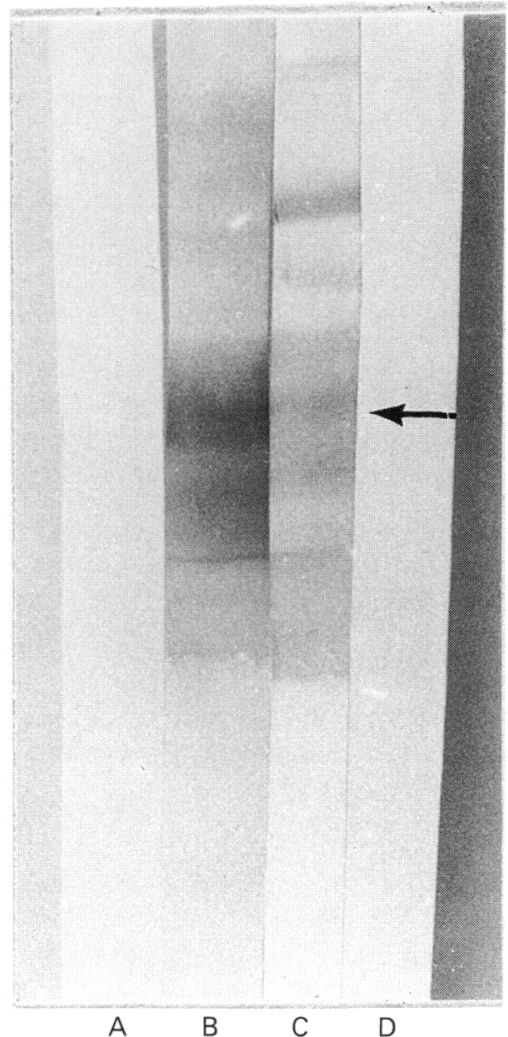

Fig. 7. Western blots of non-luteal oviductal fluid were reacted with various biotinylated lectins (primary ligand) and an avidin-biotin peroxidase conjugate (secondary ligand) to characterize carbohydrate groups on the oestrus-associated protein. Specificity of the reaction was determined by incubation with lectin in the presence of excess specific sugar. (a) Blot depicts reaction

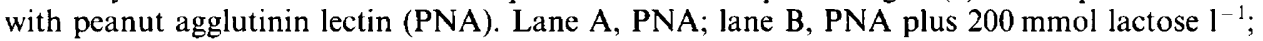
lane $C$, antiserum to oestrus-associated protein (1:100). (b) Blot shows the reaction with wheat germ agglutinin (WGA). Lane A, pre-immune serum (1:500); lane $B$, antiserum to oestrusassociated protein (1:1000); lane C, WGA treatment; lane D, WGA plus $500 \mathrm{mmol} N$-acetyl glucosamine $\mathrm{I}^{-1}$. Arrows indicate location of oestrus-associated protein.

differences in the synthesis of oestrus-associated protein with oviduct region. In every cow examined at oestrus, the ampulla synthesized significantly more oestrus-associated protein than either preampulla or isthmus in vitro. Regional differences in the production of sulfated glycoproteins from the oviduct have been reported for rabbit explants cultured in vitro using an enzyme-linked immunosorbent assay (Erickson-Lawrence et al., 1989a). Ampullar explants secreted significantly more sulfated glycoproteins (650 $\mathrm{ng}$ protein $\mathrm{mg}^{-1}$ tissue day ${ }^{-1}$ ) than isthmic explants ( $30 \mathrm{ng}$ protein $\mathrm{mg}^{-1}$ tissue day ${ }^{-1}$; Erickson-Lawrence et al., 1989b). Subsequent morphometric analysis of oviduct tissues found that there was twice as much epithelium in ampullar explants than in isthmic explants. However, this was not sufficient to account for the 20 -fold difference in sulfated glycoprotein secretion, suggesting that intrinsic production of sulfated glycoproteins was greater in the ampulla than in the isthmus.

In the present study, the incorporation of $\left[{ }^{35} \mathrm{~S}\right]$ methionine was greater in explants recovered at oestrus than in mid-luteal stage explants. Buhi et al. (1989) found that in pigs, maximum protein synthesis occurred on days $0-2$ of the oestrous cycle and that the incorporation rate of 
ampullar explants was greater than isthmus explants. The difference in incorporation rate observed in the present study probably does not account for the stage effects on the synthesis of oestrusassociated protein, since normalization by either total protein or total disintegrations per minute on gels still preserved the stage effect.

In earlier work, Joshi (1988) used polyclonal antiserum prepared against bovine oviductal flushings to demonstrate the presence of secretory granules in oviductal tissue secretion and cultured epithelial cells. However, no regional or stage effects were examined. Boice et al. (1990) localized the $97 \mathrm{kDa}$ glycoprotein to discrete granules in the secretory cells of both ampullary and isthmic regions of the oviduct from cows killed at either oestrus or during the luteal stage. We extended the observations of Boice et al. (1990) by localizing the $97 \mathrm{kDa}$ protein in the preampulla region and in oviductal tissues from pregnant cows.

We observed two types of antiserum reaction with oestrus-associated protein, both in discrete structures (all regions) and within the cytoplasm itself (ampulla and preampulla). The two types of staining observed may indicate different processing of similar glycoproteins. The polyantigenic nature of the antiserum used in the present study, and by Boice et al. (1990), does not permit discrimination of proteins of similar molecular weight which may have different pIs. In addition, the existence of at least two types of secretory granule has been suggested by electron microscopy studies of oviducts from rabbits (Brower \& Anderson, 1969; Oliphant et al., 1984) and cows (Bjorkman \& Fredricsson, 1961), indicating that the differential staining observed in these studies may be due to selective sequestration of similar glycoproteins in different types of secretory granule. Boice et al. (1990), using colloidal gold immunoelectron microscopy, noted secretory granules of various sizes, shapes and densities in the oviductal epithelium. This observation is consistent with the idea that within the family of $97 \mathrm{kDa}$ glycoproteins processing may vary.

This study represents the first examination of oestrus-associated protein in the oviducts of pregnant cows. We report that oviductal tissue and oviductal fluid, recovered from pregnant cows, reacted with antiserum to oestrus-associated protein on all days of pregnancy examined. In cows, a low level of gonadotropin secretion permits follicle development throughout pregnancy, providing an ovarian source of oestrogens during pregnancy (Peters \& Ball, 1987). Oviductal fluid, assayed for progesterone by radioimmunoassay, contained low concentrations of progesterone ( $\leqslant 0.35 \mathrm{ng} \mathrm{ml}^{-1}$ ) up to day 200 (unpublished data). In some pregnant cows, sufficient oestrogens are produced to permit behavioural oestrus. The presence of low concentrations of progesterone in oviductal fluid from a pregnant cow is therefore not inconsistent with the synthesis of oestrusassociated protein. These observations raise interesting questions about the hormonal regulation of oestrus-associated protein, but additional research is necessary to understand how the protein is regulated and what role it plays in the oviduct at oestrus and during pregnancy.

No previous work has examined the lectin-binding characteristics of oestrus-associated protein from cows. Initial lectin blots showed reactivity of bovine oestrus-associated protein with SBA, UEA, DBA, WGA and PNA. However, of these, only WGA and PNA were competitively inhibited by the appropriate sugar. Sutton et al. (1985) also found specific EGP reaction with RCA, SBA, UEA, Bandiera simplicifolia (specific for galactose or $N$-acetylgalactosamine) and especially PNA. At the concentrations of sugars used to inhibit SBA, UEA and DBA binding, no specificity for oestrus-associated protein could be demonstrated for these other lectins. However, like Sutton et al. (1985) very strong reactivity of oestrus-associated protein with PNA was detected. WGA reactivity differed from that found by Sutton et al. (1985) when ovine EGP was analysed with lectins. They found that WGA binding was only partially inhibited with $0.2 \mathrm{~mol} N$ acetylglucosamine $1^{-1}$. In the present study, WGA binding was inhibited with $0.5 \mathrm{~mol} N$ acetylglucosamine $1^{-1}$. The lower sugar concentration used by Sutton et al. (1985) may have been responsible for their inconclusive results with WGA.

$N$-acetylglucosamine residues have been detected on the peripheral zonae pellucidae of mice, rats, hamsters, cows and pigs (for review see Dunbar \& Wolgemuth, 1984). In mice, sperm galactosyltransferase binds to the terminal $N$-acetylglucosamine residues in the zona pellucida (Shur 
\& Hall, 1982). Further study determined that sperm galactosyltransferase functions as a zona pellucida receptor during fertilization (Lopez et al., 1985). In addition, oestrus-associated protein has been detected both in vitro and in vivo on the zona pellucida of cows (Wegner \& Killian, 1991). The presence of $\mathrm{N}$-acetylglucosamine residues in bovine oestrus-associated protein and the association of the protein with the zona pellucida suggests the intriguing possibility that modification of the zona pellucida by oestrus-associated protein may influence zona-sperm interaction.

We thank the staff at the Dairy Breeding Research Center for expert technical experience. This project was supported by funds from the Pennsylvania Agricultural Experiment Station and USDA Grants 85-CRCR-1-1841 and 89-372-40-4771. A preliminary account of this study has been published in abstract form.

\section{References}

Bjorkman, N. \& Fredricsson, B. (1961) The bovine oviduct epithelium and its secretory process as studied with the electron microscope and histological tests. Zeitschrift für Zellforschung und mikroskopische Anatomie 55, 500-513.

Boice, M.L., Geisert, R.D., Blair, R.M. \& Verhage, H.G. (1990) Identification and characterization of bovine oviductal glycoproteins synthesized at estrus. Biology of Reproduction 43, 457-465.

Brower, L.K. \& Anderson, E. (1969) Cytological events associated with the secretory process in the rabbit oviduct. Biology of Reproduction 1, 130-148.

Buhi, W.C., Vallet, J.L. \& Bazer, F.W. (1989) De novo synthesis and release of polypeptides from cyclic and early pregnant porcine oviductal tissue in explant culture. Journal of Experimental Zoology 252, 7988.

Dunbar, B.S. \& Wolgemuth, D.J. (1984) Structure and function of the mammalian zona pellucida, a unique extracellular matrix. Modern Cell Biology 3, 77111 .

Erickson-Lawrence, M.F., Turner, T.T., Ross, P., Thomas, T.S. \& Oliphant, G. (1989a) Sulfated oviduct glycoproteins in the rabbit: quantification by competitive enzyme-linked immunosorbent assay. Biology of Reproduction 40, 1299-1310.

Erickson-Lawrence, M.F., Turner, T.T., Thomas, T.S. \& Oliphant, G. (1989b) Effect of steroid hormones on sulfated oviductal glycoprotein secretion by oviductal explants in vitro. Biology of Reproduction $\mathbf{4 0 ,}$ 13111319.

Fox, L.L. \& Shivers, C.A. (1975) Immunologic evidence for addition of oviductal components to the hamster zona pellucida. Fertility and Sterility 26, 599-608.

Gandolfi, F. \& Moor, R.M. (1987) Stimulation of early embryonic development in the sheep by co-culture with oviduct epithelium cells. Journal of Reproduction and Fertility 81, 23-28.

Geisert, R.D., Buhi, W.C. and Fields, M. (1987) Synthesis and release of polypeptides by bovine oviductal tissue in culture. Biology of Reproduction 36 (Supplement 1), 4, Abstract.

Gerena, R.L. \& Killian, G.J. (1990) Electrophoretic characterization of proteins in oviductal fluid of cows during the estrous cycle. Journal of Experimental Zoology 256, 113-120.
Glossman, H. \& Neville, D.M. (1971) Glycoproteins of cell surfaces. Journal of Biological Chemistry 246, 6339-6346.

Joshi, M.S. (1988) Isolation, cell culture and immunocytochemical characterization of oviduct epithelial cells of the cow. Journal of Reproduction and Fertility $83,249-261$.

Kavanaugh, J.F. \& Killian, G.J. (1988) Bovine oviductal cannulations. Journal of Investigative Surgery 1, 201-208.

Kille, J.W. \& Hamner, C.E. (1973) The influence of oviductal fluid on the development of one-cell rabbit embryos in vitro. Journal of Reproduction and Fertility 35, 415423.

Killian, G.J., Chapman, D.A., Kavanaugh, J.F., Deaver, D.R. \& Wiggin, H.B. (1989) Changes in phospholipids, cholesterol and protein content of oviductal fluid of cows during the oestrous cycle. Journal of Reproduction and Fertility 86, 419-426.

Laemmli, U.K. (1970) Cleavage of structural proteins during assembly of the head of the bacteriophage $\mathrm{T}_{2}$. Nature 277, 680-685.

Leveille, M-C., Roberts, K.D., Chevalier, S., Chapdelaine, A. \& Bleu, G. (1987) Uptake of an oviductal antigen by the hamster zona pellucida. Biology of Reproduction 36, 227238 .

Lippes, J. \& Wagh, P.V. (1989) Human oviductal fiuid (hOF) proteins. IV. Evidence for hOF proteins binding to human sperm. Fertility and Sterility 51, 89-94.

Lopez, L.C., Bayna, E.M., Litoff, D., Shaper, N.L., Shaper, J.H. \& Shur, B.D. (1985) Receptor function of mouse sperm surface galactosyltransferase during fertilization. Journal of Cell Biology 101, 1501-1510.

Lowry, O., Rosebrough, N., Farr, A. \& Randall, R. (1951) Protein measurement with the folin phenol reagent. Journal of Biological Chemistry 1, 193-265.

McNutt, T., Rogowski, L. \& Killian, G. (1991) Uptake of oviduct fluid proteins by bovine sperm membrane during in vitro capacitation. Journal of Andrology 12 (Supplement), p. 41.

Malayer, J.R., Hansen, P.J. \& Buhi, W.C. (1988) Secretion of proteins by cultured bovine oviducts collected from estrus through early diestrus. Journal of Experimental Zoology 248, 345-353.

O'Farrell, P.H. (1975) High resolution two-dimensional electrophoresis. Journal of Biological Chemistry 250, $4007-4021$. 
Oliphant, G., Reynolds, A.B., Smith, P.F., Ross, P.R. \& Marta, J.S. (1984) Immunocy tochemical localization and determination of hormone-induced synthesis of the sulfated oviductal glycoproteins. Biology of Reproduction 31, 165-167.

Peters, A.R. \& Ball, F.J.H. (1987) Fertilization, conception, pregnancy and its detection. In Reproduction in Cattle, pp. 91-107. Butterworths, London.

SAS (1985) Statistical Analysis Systems, Sth edn. SAS Institute, Inc., Cary, NC.

Shapiro, S.S., Brown, N.E. \& Yard, A.S. (1974) Isolation of an acidic glycoprotein from rabbit oviductal fluid and its association with the egg coating. Journal of Reproduction and Fertility 40, 281-290.

Shur, B.D. \& Hall, N.G. (1982) A role for mouse sperm surface galactosyltransferase in sperm binding to the egg zona pellucida. Journal of Cell Biology 95, 574. 579.

Sutton, R., Wallace, A.L.C., Engel, H. \& Nancarrow, C.D. (1984a) Binding of sheep oviductal fluid proteins to spermatozoa. In Reproduction of Sheep, pp. 140-143. Eds D. R. Lindsay \& D. T. Pearce. Australian Academy of Science, Canberra.

Sutton, R., Nancarrow, C.D., Wallace, A.L.C. \& Rigby, N.W. (1984b) Identification of an oestrus-associated glycoprotein in oviductal fluid of the sheep. Journal of Reproduction and Fertility 72, 415-422.

Sutton, R., Wallace, A.L.C. \& Nancarrow, C.D. (1985) Characterization of a glycoprotein in oviductal fluid by two-dimensional electrophoresis and lectin binding to protein gel blots. Electrophoresis 6, 516-520.

Tanabe, T.Y. (1970) The role of progesterone during pregnancy in dairy cows. Pennsylvania State University College of Agriculture, Bulletin 774, p. 18.

Towbin, H., Steahlin, T. \& Gordon, J. (1979) Electrophoretic transfer of proteins from polyacrylamide gels to nitrocellulose sheets. Proceedings of the National Academy of Sciences USA 76, 4350-4354.

Wegner, C.C. \& Killian, G.J. (1991) In vitro and in vivo association of an oviduct estrus-associated protein with bovine zona pellucida. Molecular Reproduction and Development 29, 77-84.

Received 2 July 1991 